\title{
Reflecting the Process of Teaching and Listening in Two Different Approaches in Educational Philosophy
}

\author{
Aminuddin Hassan ${ }^{1}$, Norashikin Mohd Mokhtar ${ }^{1} \&$ Norhasni Zainal Abiddin ${ }^{1}$ \\ ${ }^{1}$ Faculty of Educational Studies, Universiti Putra Malaysia, Serdang, Selangor, Malaysia \\ Correspondence: Norhasni Zainal Abiddin, Faculty of Educational Studies, Universiti Putra Malaysia, 43400 \\ UPM Serdang, Selangor, Malaysia. E-mail: nonie@upm.edu.my
}

\author{
Received: August 28, $2013 \quad$ Accepted: December 9, $2013 \quad$ Online Published: February 19, 2014 \\ doi:10.5539/jel.v3n1p70 URL: http://dx.doi.org/10.5539/jel.v3n1p70
}

\begin{abstract}
In the philosophical sense, learning should be enjoyable, fun, dynamic and engaging with access of a lot of sources. While philosophical perspective in the context of this writing is regarded as integral to reflecting the quality of learning in connection to the listening process, it is also an inclination of practice with deep understanding without limitation on the aspect of the learning process itself. The question of traditional classroom and online learning is important in the learning process. To produce high achievers in education, it is important to find out the best type of learning that we can provide for students. It differed on the type of strategy the higher learning institution students used but the frequency of applying the strategy between the groups of traditional classroom and of online learning are the same. The result showed that students that subscribed to traditional classroom performed better than those who subscribed to online learning. This could be due to the fact that less instruction was provided by the teacher in online learning consequently causing the inability within students to perform.
\end{abstract}

Keywords: learning, listening, traditional classroom online learning, traditional classroom

\section{Introduction}

Elements of philosophy can be used discussing the differences between traditional classroom and online approaches. Firstly, they can be discussed metaphysically, where the benefits and weaknesses of both approaches are analysed. Secondly, in terms of epistemology, efficiency can be compared in which both approaches to relate students to the sources of knowledge. Thirdly, the positive and negative values in dealing with both approaches can be scrutinised in the viewpoint of axiology. Last but not least, in the view of logic, the rationalisation of using both approaches to teach listening in the classroom can be investigated.

In recent years, online education has gained much ground within students of higher learning institutions. Nevertheless, it brings both advantages and disadvantages at the same time. Online learning has been defined by Desmond Keegan (1988) as "the separation of teachers and learners which distinguishes it from face-to-face education, the influence of an educational organization which distinguishes it from self-study and private tutoring, the use of a computer network to present or distribute some educational content and the provision of two-way communication via a computer network so that students may benefit from communication with each other, teachers, and staff" (as cited in Comey, 2009). This online learning generally can also can be described as long-distance learning, web-based education, and virtual education. Even though the traditional classroom approach also has it significance in developing the process of learning, the importance of online learning has been investigated thoroughly by many researchers.

In reality, online learning is convenient to the learners as it gives space and time for them. But there are limitations to it where there is no physically face-to-face interaction between the teachers and students (Kirby, 1999; Kruger, 2000). It is to be said that whether it is not comfort that values the learning but the interaction as a total experience in classroom make students prefer to sit in a classroom, laboratory, or conference room with other learners and the instructor (Simonson, 1997; Rothmund, 2008). Both approaches can give advantages and disadvantages as we know what the best for the students. It is not the approach itself that can only contribute to the learning process but the student's readiness and their strategy need to take into consideration. 
Traditional classroom can be defined as a two way interaction between teachers and students. This is a situation of which interaction between two parties and they can interact face-to-face in the classroom. Some researchers claim that traditional classroom is the combination of relationship between teacher and students, relationship between students and both subjects and method of learning, interpersonal relationship among students, and also students' perception of the structure of the class (Jou, 2010). Dewey (1938), in a study of Comey (2009) theorized that learning can take place where students join together in a social context, such as a classroom, to manipulate materials and ideas based on the meaningful experience. On the other hand, online learning has advantages for the students who have low level of self-esteem and are afraid and shy to throw out ideas in the classroom even if they have excellent points to give. This approach somewhat teaches them to communicate and increase their level of confidence. Students also will be able to learn by themselves doing exercises and practices online and they have times to do it by just turning on the computers and connecting to the internet.

The students will also develop ICT (Information Communication Technology) skills that required by many company or institution when applying for jobs. Online learning in some institutions require students to partake in group discussions, one-to-one tutorials with teachers, tests completion, blogs comments, assignments submission, and exams all online. Online learning is very convenient to both teachers and students because they can access it anytime and anywhere to their convenience. The class discussion also becomes more successful for the students as they can build up more confidence. This happens when the shy and less confident students try to contribute more in discussions and also be brave enough to share own ideas and views and these students will talk more to more people because it is an easy way to approach other people when the others don't see them or one to one conversation only.

There are also institutions that allocate grades for the online contributions as a consideration for the students to understand the course or subjects well. Students can also get through the content over and over again if they missed the lecture. As in online learning we have tools to playback the tutorial and we learn it in our own pace so that we can absorb content and engage to our own learning. Listening is a crucial skill to be learnt. There are so many freeware and courseware out there to improve listening online. This is one of the ways to get students interest to do listening rather than boring activities in class. We cannot deny that traditional classrooms gives students valuable output and input in students learning but with the integration of online learning in curriculum and adapting it according to the students need is much better as the students will be more interested and enjoyable in their learning process.

The general purpose of this research is to explore whether online learning resulted in increased students' performance compared to traditional classroom teaching. This study has defined several objectives to which are to investigate what type of learning that can provide high achievement of the students and to determine whether there is any significant difference in metacognitive awareness listening strategies students used in learning listening online and learning listening in a traditional classroom. Thus, this research aims to compare between two different approaches of teaching listening and which type of approach increased students' performance.

In this study, listening strategies were also taken into consideration and were compared between both groups of online learning and traditional classroom learning. Both traditional classroom and online learning play a role in learning process. It was investigated by many researchers before and important findings had been revealed. Both play different roles. There are researchers who came out with the solution of the blended learning. Many other factors need to be considered. Online learning is also considered distance learning. There were generations before that had started using the distance learning method in delivering the materials but they needed to endure the lack of interactive communication between students and teachers (Katz, 2002). However, reality has changed nowadays. Technology has become more developed and now there are easy access on the internet and web. It also enhances learning with the availability of interactive video, email, and World Wide Web technologies, distance learning which have been redefined to include teacher-student interaction (Katz, 1998, 2000). This study therefore aims to provide better solutions and suggestions for the learners based on the results and data analysis. It is to resolve the problem on why students in universities get lower marks even though the university has provided them with good facilities and has proposed the use of coursewares integrating ICT into learning process.

\section{Method}

An English courseware was used and prepared for this research to investigate the best approach in teaching listening. The participants were chosen to implement the study. The participants from the experimental group underwent the courseware and the control group used the normal traditional classroom lesson which has been copied from the courseware. The study was implemented in two different time of learning process. The 
questionnaire from Metacognitive Awareness Listening Questionnaire (MALQ) was used to understand participants' strategy on listening. The students had already been introduced and taught about listening strategy in their first class to check whether listening strategy relates to the approach of teaching.

\subsection{Description of Study}

A sample was taken from an students who are of intermediate proficiency that were required to take the English courses that were offered by the Pusat Pengajian Umum (General Learning Centre) and their level of proficiency in English was intermediate measured by the Malaysian University English Test (MUET) that they took. This type of sampling did not generalize the whole group of students in the university and it is only the group that the researcher teaches throughout the semester. The targeted population for this study were the students in the Syariah and Law Faculty. Almost all of the students in USIM are made compulsory to attend the English course offered by the Pusat Pengajian Umum for the first and second year students. This English course is a requirement for them to graduate and it shows the importance of English Language for the university students. The participants in two different groups from the Syariah and Law Faculty have been selected and consisted of 22 students in control group and 22 students in the experimental group.

The location of study was very specific. The study was conducted in local university in Negeri Sembilan. The selected higher institution selected was Universiti Sains Islam Malaysia (USIM). This university is located in Nilai, Negeri Sembilan which it is easy for the researcher to get the participants as the university emphasizes on Science and religious subjects and the vision is to Foster academic excellence and an ummah to contribute towards human progress, nation building and the advancement of the world.

\subsection{Description of Instrument}

In this study, the instruments used were the courseware from the internet and the adapted questionnaire from Vandergrift et al (2006). The courseware used was designed for English Second Language learners and the selected courseware that have chosen and mentioned earlier is English Listening Lesson Library Online (ELLLO). The audio provided was clear and the teacher can save the audio to be used in the traditional classroom lesson also. The teacher will chose two topics per class and assigned the participants to do that in every class throughout the month.

The questions in the courseware include vocabulary questions, comprehension question, and fill in the blanks. It is the same task for the traditional classroom which the students will be given the same test questions that have been chosen by the teachers in experimental group. The audio is also taken from the courseware itself so that there will be no bias when it comes to comparing the results for both class approaches. Both sets of the questions will have the same amount of item in order to balance the scoring. In this courseware, there are lots of listening exercises from various countries. The themes and topics include the whole world issues and it is interactive. The students will be given the pre-test at the beginning of the month and the post-test at the end of the month. This study is conducted throughout the month to compare the students' performances. After the students took their post-test for both groups, the teacher will distribute the questionnaire of the listening strategy. This is to compare listening strategies between these two groups. For the scoring, the researcher used the pre-test and post-test to compare the students marks for the month.

At first, the pre-test was conducted for both groups to check the participant's level of proficiency. After a month, a post-test was conducted to compare between these two groups performances. The questionnaire used was Metacognitive Awareness Listening Questionnaire (MALQ). This questionnaire was adapted from Vandergrift et al (2006). This questionnaire is quantitative and used the Likert 6-scales which the researcher interpreted using SPSS. The researcher chose Likert 6-scales so that there is no unsure respond from the students and they cannot hedge in answering the questionnaire. There were 21 items about listening strategies which did not include demographic data of the participants. The data came from three resources which were the pre-test and post-test, results for both online learning and traditional classroom learning and the listening strategies that the students used in class before the listening lesson begin.

The research findings presented were obtained from the data and results taken from the instrument used in this study which are pre-test and post-test results from courseware, and metacognitive awareness listening questionnaire. These data were analysed using SPSS version 19. The finding from the data and students responds towards the questionnaire will be discussed in the next chapter. The respondents for this study were the students in Syariah and Law Faculty that were involved two average classes of 22 students for both. The students' level of proficiency was quite low as they needed to sit for English courses to fulfil university requirement for them to 
graduate. In this study, the students had to undergo one month of research study with 8 lessons and about 480 minutes all together.

\subsection{Data Collection Procedure}

This study was conducted for a month for the students to have time to learn the process through different approaches. In order to measure the student's performance in the English listening task, this study was conducted to know which types of learning can provide better outcomes to the students. After the students have taken the pre-test in the beginning of the month, they went through the process for the rest of the month. At the end of the month, the teacher gave a second test (post-test). The scores for both groups were compared to check their performance in listening. After both groups have gone through the exercises and tests, the questionnaires of listening strategy (MALQ) was distributed to the students. The data from the questionnaire will be used to determine the significance of listening strategies between two approaches of listening.

\subsection{Data Analysis}

Pre-tests and post-tests were conducted to observe the students' performance on both approaches of listening class. Both tests measured the best approach for the students to learn listening after they have gone through the listening class for a month. The tests will be measured by the mean of the test scores and the highest mean score indicated that the traditional classroom approach was better than the other. After that, T-test was conducted based on the mean to identify the difference among these two approaches. Nevertheless, if there is no significant difference, the approach is the same and not indicate that any approach is effective than other. The next step was to check if there is significant difference between online learning and traditional classroom learning in listening strategy used by the students by using the T-test.

\section{Results}

In the post-test, the mean results of students' performance in both groups intended to indicate the effectiveness of comparative in two course delivery methods are shown below

Table 1. Means and standard deviations in the post-test

\begin{tabular}{lll}
\hline Method & Means & Standard Deviation \\
\hline Online Learning & 74.5455 & 14.7123 \\
Traditional Classroom Learning & 79.5455 & 12.9016 \\
\hline
\end{tabular}

Based on Table 1, there are significant differences between the mean scores in the achievement test for both the experimental group (online learning) and the control group (traditional method). The mean scores of the experimental group and control group are 74.55 and 79.55 respectively. The difference in mean scores between the two groups' is 5.00 . The independent T-test revealed that there is a significant difference between traditional and online learning as $t(42)-2.156, \mathrm{p}<.05$. Since sig $-t(.037)$ is lower than $\alpha$ at.05 level of significance we reject the null hypotheses. The researcher employed this independent sample T-test to find out the statistical significance of the difference in post-test result for both groups. The significant level is lower than the postulated significance level $(\alpha<0.05)$ and indicates that there is a significant effect of the use of traditional classroom learning than a computerized software program on the achievement of students. This effect is in favour of the control group who learnt through traditional learning which from this study shown that traditional learning is more effective than online learning. From this result, it shows that the students need something that they are interested to learn so that if they like and satisfied with the activity, the learning will take place. According to Gagne, et al. (1992); and Reeves, et al. (2002), it has been studied that based on teacher- centred approach, the role of activity is as the vehicle for the practice. From the figure below we can say that the traditional classroom or control group performed better than the online learning classroom which is control group. 2 students had got D's in the post-test but none of them were from the traditional classroom. On the other hand, there are about half of the class got an A for the post-tests in traditional classroom but only quarter of the students in online learning classroom got an $\mathrm{A}$ in the test.

\subsection{Planning and Evaluation Strategies}

The table below shows the listening strategies students used in learning listening skills. It comprises of five items which are: planning and evaluation, directed attention, person knowledge, mental translation and problem 
solving. The first table was the result of comparison of online learning and traditional classroom learning in using planning and evaluation strategy. The table shows that students in online learning normally think back how they listen and about what they should do next time, periodically ask whether satisfied with the level of comprehension, and already have a goal in their mind.

This table denotes that item no. 1 in planning and evaluation strategy has no difference between online and traditional approach. Students' in both classes has mentally planned their listening strategies before they start listening. In item no. 2, students in online learning prefer to think of similar previously encountered text.

Table 2. Mean scores for planning and evaluation strategies

\begin{tabular}{llll}
\hline No & Items & $\begin{array}{l}\text { Online learning } \\
\text { (mean) }\end{array}$ & $\begin{array}{l}\text { Traditional classroom } \\
\text { learning (mean) }\end{array}$ \\
\hline 1 & $\begin{array}{l}\text { I mentally plan on the strategies I will } \\
\text { use before I start listening. }\end{array}$ & 5.00 \\
2 & $\begin{array}{l}\text { Before I listen, I will think about a } \\
\text { previous similar text that I have } \\
\text { encountered. }\end{array}$ & 4.64 \\
3 & $\begin{array}{l}\text { After I listen, I reflect on the way I } \\
\text { have listened and different methods I } \\
\text { would apply in the future. }\end{array}$ & 4.73 \\
4 & $\begin{array}{l}\text { During listening, I constantly ask } \\
\text { myself if I am satisfied with the } \\
\text { amount of information I understand. }\end{array}$ & 4.27 \\
\hline $\begin{array}{l}\text { I have an aim in mind when I am } \\
\text { listening. }\end{array}$ & 4.32 & 4.18 \\
Total mean & 22.92 & 22.59 \\
\hline
\end{tabular}

\subsection{Directed Attention Strategies}

Table 3 below shows that students in online learning concentrate more on the text when they have trouble understanding, and try to get back on track when they lose concentration compared to the traditional classroom learning but, when have difficulty understanding what they hear easily give up and stop listening. In the traditional classroom, when the mind wonders, they will recover concentration right away.

Table 3. Directed attention strategies

\begin{tabular}{|c|c|c|c|}
\hline No & Items & $\begin{array}{l}\text { Online } \\
\text { learning }\end{array}$ & $\begin{array}{l}\text { Traditional classroom } \\
\text { learning }\end{array}$ \\
\hline 1 & $\begin{array}{l}\text { I concentrate more on the text that I have } \\
\text { trouble understanding. }\end{array}$ & 5.5 & 5.05 \\
\hline 2 & $\begin{array}{l}\text { If my mind wanders, I will regain my } \\
\text { concentration immediately. }\end{array}$ & 4.73 & 4.82 \\
\hline 3 & $\begin{array}{l}\text { I try to get back on track when I lose } \\
\text { concentration }\end{array}$ & 5.23 & 5.00 \\
\hline \multirow[t]{2}{*}{4} & $\begin{array}{l}\text { When it becomes hard for me to } \\
\text { understand what I hear I give up and stop } \\
\text { listening. }\end{array}$ & 4.82 & 2.86 \\
\hline & Total mean & 20.28 & 17.73 \\
\hline
\end{tabular}




\subsection{Person Knowledge Strategy}

Table 4 below shows that online learning student have a perception on difficulties in listening in English rather than reading, speaking and writing. Even though they said that it was challenging, they do not feel nervous when they are listening in English compared to the traditional classroom.

Table 4. Mean scores for person knowledge strategies

\begin{tabular}{lllll}
\hline No & Items & $\begin{array}{l}\text { Online } \\
\text { Learning }\end{array}$ & $\begin{array}{l}\text { Traditional } \\
\text { Learning }\end{array}$ & Classroom \\
\hline 1 & $\begin{array}{l}\text { To me, listening is harder than reading, } \\
\text { speaking and writing skills in English. }\end{array}$ & 2.27 & 2.91 \\
2 & $\begin{array}{l}\text { Listening comprehension in English is } \\
\text { difficult for me. }\end{array}$ & 4.77 & 4.95 \\
3 & $\begin{array}{l}\text { I do not feel anxious when I listen in } \\
\text { English. } \\
\text { Total means }\end{array}$ & 12.55 & 3.55 \\
\hline
\end{tabular}

\subsection{Mental Translation Strategies}

Table 5 below represents that online learning students frequently translate mentally as they listen rather than traditional learning. But, traditional classroom learning frequently translate keywords as they listen. Translate word by word as listen is not a good strategy in listening as listeners should understand what they listen but not only focus on word by word and table above shows that online learning students in favour of doing it.

Table 5. Mean scores for mental translation strategies

\begin{tabular}{lllll}
\hline No & Items & Online Learning & $\begin{array}{l}\text { Traditional } \\
\text { Learning }\end{array}$ & Classroom \\
\hline 1 & I translate mentally during listening. & 4.77 & 4.60 \\
2 & I translate keywords during listening. & 4.68 & 4.73 \\
3 & I translate word by word during listening. & 3.05 & 2.73 \\
& Total means & 12.50 & 12.06 \\
\hline
\end{tabular}

\subsection{Problem Solving Strategies}

The table below indicates that online learning frequently use words they already knew to guess other words that don't understand and relate what they understand with what they know about the topic. They also used knowledge and experience to help in comprehending, correct their interpretation when they realised that it is incorrect and guessed the meaning of the word whether it fits the whole picture. Traditional classroom learning from the results indicates more on using the main idea of the script and try to guess the meaning from what was heard. 
Table 6. Mean scores for problem solving strategies

\begin{tabular}{|c|c|c|c|}
\hline No & Items & $\begin{array}{l}\text { Online } \\
\text { Learning }\end{array}$ & $\begin{array}{l}\text { Traditional Classroom } \\
\text { Learning }\end{array}$ \\
\hline 1 & $\begin{array}{l}\text { When I don't understand a new word, I will } \\
\text { guess the meaning of the words using words } \\
\text { I already know. }\end{array}$ & 4.68 & 4.55 \\
\hline 2 & $\begin{array}{l}\text { As I listen, I relate what I understand with } \\
\text { my previous knowledge of the topic. }\end{array}$ & 5.23 & 5.05 \\
\hline 3 & $\begin{array}{l}\text { To help me comprehend what I listen, I use } \\
\text { my knowledge and experience. }\end{array}$ & 5.18 & 5.14 \\
\hline 4 & $\begin{array}{l}\text { If my interpretation is incorrect as I listen, I } \\
\text { instantly correct my interpretation. }\end{array}$ & 4.77 & 4.55 \\
\hline 5 & $\begin{array}{l}\text { I use main idea of the script to help me guess } \\
\text { the meaning of words that I do not } \\
\text { understand. }\end{array}$ & 4.68 & 4.86 \\
\hline \multirow[t]{2}{*}{6} & $\begin{array}{l}\text { When guessing the meaning of a word, I } \\
\text { reflect on everything else that I have heard, } \\
\text { to see if my guess fits. }\end{array}$ & 4.68 & 4.45 \\
\hline & Total mean & 29.22 & 28.63 \\
\hline
\end{tabular}

\subsection{Description on Pre-Test}

Table 7 below represents the mean scores and standard deviation in pre-test. The t-test result shows no significant difference in online learning and traditional classroom learning. It shows that there is no significant difference in students' proficiency level. The scores in t-test was $t(42)=-.431, p<.05$. Since sig-t (.669). This means that both groups were quite similar in this case.

Table 7. Mean scores and standard deviation in pre-test

\begin{tabular}{lll}
\hline Listening strategies & Mean & Standard deviation \\
\hline Online learning & 87.05 & 11.92 \\
Traditional classroom learning & 12.55 & 12.55 \\
\hline
\end{tabular}

\subsection{Students Listening Strategies}

Table 8 below indicated the result of t-test which there is no significant difference between online learning and traditional classroom learning in terms of strategies that they used. Which the t-test result is stated $t(42)-.403$, $\mathrm{P}>.05$. since sig $\mathrm{t}-(.689)$. This is to be concluded that even though there are items that frequently used by the students in online learning, it is the same with students in traditional classroom too which have frequently used of other items in listening strategies. This is because the results from t-test which came out with no significant difference. One of them is Vandergrift et al (2006). He claims that there are also many studies have evidence that metacognitive awareness of the learners can give effect on the performance in listening and provide good outcome in learning (Boekaerts, Pintrich, \& Zeidner, 2000; Bolitho et al., 2003; Eilam \& Aharon, 2003; Mokhtari \& Reichard, 2002; Palmer \& Goetz, 1988; Schoonen, Hulstijn, \& Bossers, 1998; Victori \& Lockhart, 1995; Winne, 1995; Zimmerman \& Schunk, 2001) all these shows that either online learning or traditional learning together with listening strategies give effects on students performance. 
Table 8. Means and standard deviation in students listening strategies

\begin{tabular}{llll}
\hline Group & $\mathrm{N}$ & Mean & Std. Deviation \\
\hline experimental & 22 & 96.1818 & 1.95251 \\
traditional & 22 & 95.1818 & 1.52843 \\
\hline
\end{tabular}

\section{Conclusion}

The researcher compared the data using t-test in considering on what type of instruments and data analysis procedure to be used. This was to check on significant difference based on research questions. Results showed that after a month, traditional classroom learning indicates the effectiveness rather than online learning. This is checked based on the post-test given at the end of the month. The data analysis showed that students in the traditional classroom performed better result than their online counterparts. This could be due to something wrong with the courseware used by the teacher. Less instruction provided by the teacher might explain on why the students in online learning could not perform in the listening task. It seems that online learning is interesting to be applied in classroom and if it is just been disregard it will be a waste as we need to be more IT savvy for the need of future generation. The duration of the study is too short and it will be one of the reasons why the study has no effect.

In listening strategies, based on the findings, there is no significant difference between two groups of approach. The students use the same strategy either online classroom or traditional classroom. It differs on what type of strategy they used but the frequency that they apply the strategy between two groups are the same. Even though the method used is different, the strategies that they used are still the same. In this regards, the research result have been able to give a very valuable conclusion and information on the common strategies used and always appreciated.

\section{References}

Boekaerts, M., Pintrich, P., \& Zeidner, M. (2000). Handbook of self-regulation. San Diego: Academic Press.

Bolitho, R., Carter, R., Hughes, R., Ivanic, R., Masuhara, H., \& Tomlinson, B. (2003). Ten questions about language awareness. ELT Journ Table 8: Means and Standard Deviation in Students Listening Strategiesal, 57(3), 251-260. http://dx.doi.org/10.1093/elt/57.3.251

Dewey, J. (1938). Experience and education. New York: Collier MacMillan.

Gagne, R. M., Briggs, L. J., \& Wager, W. W. (1992). Principles of instructional design (4th ed.). Orland FL: Harcourt, Brace, Jovanovich.

Jou, Y. J. (2010). A study of English listening strategies applied by technological university students. Journal of TOKO University, 4(2). 1-16.

Katz, Y. J. (1998). The relationship between distance learning methods and satisfaction and achievement of college students. In G. Davies (Ed.), Teleteaching 98: Distance Learning, Training, and Education (pp 569-578). Austrian Computer Society (OCG), Vienna.

Katz, Y. J. (2000). The comparative suitability of three ICT distance learning methodologies for college level instruction. Educational Media International, 37(1), 2530. http://dx.doi.org/10.1080/095239800361482

Katz, Y. J. (2002). Attitudes affecting college students' preferences for distance learning. Journal of Computer Assisted Learning, 18, 29. http://dx.doi.org/10.1046/j.0266-4909.2001.00202.x

Keegan, D. (1988). On defining distance education. In D. Sewart, D. Keegan, \& B. Holmberg (Eds.), Distance Education: International Perspectives (pp. 6-33). London/New York: Routledge.

Kirby, E. (1999). Building interaction in online and distance education courses. Paper presented at the Society for Information Technology Teacher Education International Conference. San Antonio, TX. (ERIC Document Reproduction)

Kruger, K. (2000). Using information technology to create communities of learners. In B. Jacoby (Ed.), Involving commuter students in learning. New directions for higher education (pp. 59-70). San Francisco: Jossey-Bass.

Mokhtari, K., \& Reichard, C. (2002). Assessing students' metacognitive awareness of reading strategies. Journal of Educational Psychology, 94, 249-259. http://dx.doi.org/10.1037/0022-0663.94.2.249 
Simonson, M. (1997). Distance education: Does anyone really want to learn at a distance? Contemporary Education, 68(2), 104-107.

Reeves, C. T., Herrington, J., \& Oliver, R. (2002). Authentic activities and online learning. Proceeding from Higher Education Research and Development Society of Australasia (HERDSA 2002) conference.

Rothmund, C. A. (2008). Correlation between Course Interactivity and Reported Levels of Student Satisfaction in Hybrid Courses. AAT 3297548. Retrieved August 10, 2011, from http://proquest.umi.com/pqdweb?did=1483477611\&sid=1\&Fmt=2\&clientId=36652\&RQT=309\&VName= PQD

Schoonen, R., Hulstijn, J., \& Bossers, B. (1998). Metacognitive and language-specific knowledge in native and foreign language reading comprehen-sion: An empirical study among Dutch students in grades 6, 8 and 10 . Language Learning, 48, 71-106. http://dx.doi.org/10.1111/1467-9922.00033

Vandergrift, L. (1997). The comprehension strategies of second language (French) listeners: A descriptive study. Foreign Language Annals, 30(3), 387-409. http://dx.doi.org/10.1111/j.1944-9720.1997.tb02362.x

Vandergrift, L. (1999). Facilitating second language listening comprehension: Acquiring successful strategies. ELT Journal, 53(3), 168-176. http://dx.doi.org/10.1093/elt/53.3.168

Vandergrift, L. (2003). Listening: theory and practice in modern foreign language competence. Retrieved January 4, 2009, from http://www.llas.ac.uk/resources/gpg/67

Vandergrift et al. (2006). The Metacognitive Awareness Listening Questionnaire: Development and Validation. Language Learning, 56(3), 431-462. http://dx.doi.org/10.1111/j.1467-9922.2006.00373.x

Victori, M., \& Lockhart, W. (1995). Enhancing metacognition in self-directed language learning. System, 23, 223-234. http://dx.doi.org/10.1016/0346-251X(95)00010-H

Winne, P. (1995). Inherent details in self-regulated learning. Educational Psychologist, 30, 173-187. http://dx.doi.org/10.1207/s15326985ep3004_2

Zimmerman, B. J., \& Schunk, D. H. (2001). Self-regulated learning and academic achievement. Mahwah, NJ: Erlbaum.

\section{Copyrights}

Copyright for this article is retained by the author(s), with first publication rights granted to the journal.

This is an open-access article distributed under the terms and conditions of the Creative Commons Attribution license (http://creativecommons.org/licenses/by/3.0/). 